\title{
An Existential Hermeneutic Philosophical Approach to Project \\ Management
}

Bradley Rolfe, Sydney University Business School, Sydney, Australia; Macquarie Graduate School of Management, Macquarie University, Sydney, Australia

Steven Segal, Macquarie Graduate School of Management, Macquarie University, Sydney, Australia

Svetlana Cicmil, University of West England, Bristol, UK

\begin{abstract}
The philosophies of Martin Heidegger and Richard Rorty are used to redescribe the fundamental assumptions underpinning project management. Rather than viewing project management as merely a science, the significance and value of philosophy for project management are developed. The philosophical practice of redescription as a way of responding to existential disruptions of the lived experience of managing projects is seen as vital not only to being a project manager but to describing project management.
\end{abstract}

KEYWORDS: existential; hermeneutic; disruption; redescription; Heidegger; Rorty

\section{INTRODUCTION}

This article argues that there are certain conditions under which philosophy becomes essential for project management. These conditions are called existential disruptions. Existential disruptions are those kinds of disruptions in which a practitioner's habits or conventional ways of doing things are threatened and can no longer be taken for granted. There are a number of philosophical practices that can enable project managers to work with and through existential disruptions both to their own practices and the practices of their clients. Examples include: the reframing or redescribing of assumptions, working through the space of 
disruption and, bringing into being the results of a project. It will be argued that it has been a historical mistake to view project management only through the dominant discourse of a scientific prism, which in its essence, is focused on implementing a representation of a scenario designed in terms of the rules of logic and science rather than creating new possibilities in the context of disruption and the unforeseeable contingencies of day-to-day practice.

The word unforeseeable is used purposefully to counteract the suggestion that lived experience is predictable. The language of prediction belongs to a particular epistemologythat of science-yet science does not deal with everyday lived experience. The ontology of science is limited to dealing with the objects of experience but not the experience itself. Philosophy deals with lived experience rather than the objects of lived experience. This is especially the case in the field of philosophy called existential hermeneutic philosophy. Existential hermeneutic philosophy is a broad discipline of philosophy, which began in the market place of ancient Greece and returned in the 19th and 20th centuries through the philosophy of Martin Heidegger, existentialism, and some forms of American pragmatism that promote practices of continuous redescription and of "keeping the conversation going" (1979), as Rorty calls it.

The way in which we will present the significance of philosophy for project management is with a general and accessible introduction to the philosophy of Martin Heidegger. We will then provide a description of the role of disruption in project management, utilizing the philosophy of Thomas Kuhn, before moving to reconstruct the way of being of managing projects in terms of reframing or, more specifically, in terms of Richard Rory's notion of redescription. In terms of the latter, we shall maintain that an essential dimension of project management is holding effective conversations for redescription. 


\section{Philosophy and Heidegger}

This article draws on the framework of the philosophy of Martin Heidegger; the works of this philosopher, however, are notoriously difficult to read. In order to make his writing accessible to an audience not familiar with his work, we will use a particular interpretation of his work developed by Segal, in his book, Management Practice in the Context of Creative Disruption: Existential Skills for Managers, Management Researchers and Educators (2015). Segal maintains that Heidegger's philosophy, especially in his early work, can be thought of in a circular relation of three movements: convention, disruption, and authenticity or envisaging new possibilities. It is crucial to appreciate that Heidegger's view of philosophy does not mean a rejection of science but, rather as Rorty would say, a re-description of it in a broader context. The danger with a scientific view of project management is not the science itself but what we do with it. Science is constituted as the dominant and legitimate discourse through which to gain access to the community of project management practitioners. Heidegger allows us to see that science is important but it is not the only "grammar," as he calls it that is helpful in project managing. Project managers need to be able to move between a range of "grammars" or language games in a business: the way in which, for example, marketing people speak; the way in which finance people speak and think; the way in which engineers speak, and so forth. Philosophy is that activity that allows us to work between different disciplinary or functional languages through the art of redescription.

Heidegger views philosophy as a destruction of conventions that clear the way for disclosing new possibilities. To phrase in the technical language of Heidegger: "Tradition takes what has come down to us and delivers it over to self-evidence; it blocks our access to those primordial 'sources' from which the categories and concepts handed down to us have been in 
part quite genuinely drawn" (1996, p. 43). Heidegger wants to engage in activity of what he calls "destroying" the tradition or conventions, until we arrive at the "primal" sources, so that new possibilities of ways of being can be disclosed. It is the basis of, as he puts it, staking out "positive possibilities" (1996, p. 44). It is by destroying the familiar conventions in which we are embedded that we create the space for disclosing new worlds. It is not that Heidegger wants the destruction of conventions for its own sake however; rather, it is under the conditions of changing circumstances - where the traditions bog us down in the past rather than allowing for the disclosing of new possibilities, ways of doing things or worlds-where the tradition becomes a set of empty rituals. It is when these empty rituals are mimicked in the state of existential anxiety, and we can no longer rely on the traditions of the past, that a destruction of traditions emerges as a possibility. Thus, it is in the context of a range of lived experiences that destruction opens up as a possibility. On the other hand, according to Heidegger, there is often a temptation to play it safe, become defensive, and not change our ways of doing things, thinking, and being with the way in which circumstances change. This, as we shall see, is a more dangerous option than destruction for Heidegger; for in the former view, we become wedded to a past that has been surpassed.

Although it is tempting to say that, for Heidegger, destruction is a method or process, it is in fact more than both of these. It expresses itself as an inhabited way of being; it is experienced as a disruption of our habitual and conventional ways of doing things; and, in its most extreme case, this disruption is the experience of existential anxiety. In less intense cases, disruption functions as a shift in perception in which our attention is transformed from an involvement in using entities as equipment to examining equipment as an object. In the same way, conventions and disclosures are ways of being; they aren't just detached ideas but embodied scripts that are encountered in the ways in which we do things. It is impossible to 
fully explain how there are ways of being until the phenomenon of ways of being has been explained. In other words, the framework for making sense of the notion of a way of being itself needs to be established first.

It is reasonable to ask: Why introduce Heidegger into the field of management in general and project management in particular? Heidegger's notion of "disruption" cuts across many fields within management ${ }^{1}$; for example, in the context of economics, Joseph Schumpeter (1955) wrote about a "creative destruction," which is focused on capitalism or the free market and is a dynamic process that constantly destroys and creates itself. The free market constantly destroys the conventions of industries and businesses and discloses new ways of doing things - - as, for example on-line retail is constantly destroying the conventions of buying and selling in a store and disclosing the possibility of exchange on-line - or on-line education is destroying conventional forms of education and disclosing new possibilities.

Christenson and Overdorf (2000) have written on the way in which technology creatively destroys organizations and forms of economic life. Fernando Flores (2000) writes on the way in which careers are being creatively destroyed, and Nietzsche (1969) wrote on the way in which the death of God creatively destroyed forms of life in general. While Heidegger did not write about creativity per se, he did call his philosophical methodology "destruction" (1996) and considered destruction the basis for disclosing new worlds and possibilities. Indeed, both Nietzsche and Heidegger articulated the challenges to be faced in a world of creative destruction; thus, it is not unreasonable to begin a text on Heidegger for managers with a work that deals with the ways in which new possibilities emerge out of practices of disruption.

\footnotetext{
${ }^{1}$ In his essay, "What Is Metaphysics?" Heidegger engages in a "destruction of logic," demonstrating that logic is not able to ground itself; however, an elaboration on this would be a paper in its own right.
} 
In the field of marketing, Jean-Marie Dru wrote a book called Disruption: Overturning Conventions and Shaking Up the Marketplace (1996) There are three moments in Dru's dynamic logic of disruption: convention, disruption and vision and he believed that it is through the disruption of existing conventions that new visions are disclosed.

According to Dru, conventions consist of background scripts that allow us to get on with the task of everyday practical coping without having to think about them. Conventions allow us to do things - such as drive cars, sit in lecture theatres, manage a business, and go to the movies - without having to think about how to conduct ourselves in each of these contexts. It is because we do not have to think of them while performing acts based on them that they are in the background rather than the foreground of our attention. In the context of management, there are conventions for managing, leading, and following and they enable the managers to perform the activities of managing without having to think about managing while they are managing; leading while they are leading; and following while they are following. Conventions thus allow us to cope without having to think about our conventions for coping. Dru states: "Although conventions are everywhere, they are generally hard to see. These are things that we don't even notice because they are so familiar. ... Depending on the case, we will talk about unquestioned assumptions, good old common sense, or the current rules of the game." (1996, p. 56)

Conventions open and close possibilities. They allow us to see the world in certain ways and not in other ways; for example, the conventions of finance in management allow the finance manager to see things in one way, not in another way; someone who has been habituated in marketing will see the world in one way and not in another way; similarly, a manager with an engineering background will see the world in one way, not in another way. In Organizational 
Behavior, Bolman and Deal (2013) call these "frames." Our frames open up and close down possibilities and because they exist in the background of our attention, we do not even begin to know that our way of seeing is shaped and limited by a set of frames or conventions. We assume that the way in which we see the world is the natural way in which to see the world. Although not expressed by Dru, for Heidegger it is important to say that we are embedded in conventions and frames for seeing things. We are also embedded in habits of practice and ultimately in existence itself. We are hardly ever free of being embedded in conventions, frames, and habits of practice. Moments of estrangement or perplexity disrupt our habitual and conventional ways for doing things.

Like Heidegger, Dru believes that it takes an act of disruption to see our own frame or set of conventions, to question them and to open up new possibilities. Dru sees the act of disruption in terms of the notion of defamiliarization of our familiar, conventional way of seeing the world. When we are estranged from our conventions through acts such as surprise, perplexity, or disbelief, we stand at an emotional distance from our beliefs, such that we begin to see what we had taken for granted. Dru says that the "idea of viewing the familiar in a different manner" is achieved by making the "unstrange strange, the familiar unfamiliar." (1996, p. 69). The act of de-familiarization emotionally distances us from our familiar conventions, such that we can see them and question them. We cannot do this when we are simply embedded in them. The act of questioning our conventions paves the way for seeing new possibilities or disclosing new worlds.

Although Dru does not acknowledge the philosophical ancestry of the notion of defamiliarization, it has a long history. It is expressed by, for example, Richard Rorty, who maintains that "The attempt to edify (ourselves or others) may consist in ... the attempt to reinterpret our familiar surroundings in the unfamiliar terms of our encounter with other culture[s] or historical periods" (1979, p. 360). Rorty calls the process of de-familiarization 
through disruption, "redescription." Redescription takes "us out of our old selves by the power of strangeness and aids us in becoming new beings" (Rorty, 1979, p. 360). A version of the same idea may be found in the work of Spinosa, Flores, and Dreyfus (1997), who demonstrate how disruption of a paradigm is the basis for disclosing new worlds. They focus on our "ability to appreciate and engage in the ontological skill of disclosing new ways of being" (1997, p. 1). This ability, they claim, relies on becoming "sensitive to anomalies that enable us to change the style of our culture" (1997, p. 181).

None of the authors above makes reference to the Heideggerian proposition that disruption through de-familiarization is an existential experience. Existential implies that it is not only a cognitive or intellectual activity that is disrupted, but a disruption that is experienced with one's whole being. An author who allows us to make clear sense of this existential form of disruption is Douglas-Mullen, who in a work on Kierkegaard says: "One feature peculiar to humans is the ability to detach ourselves from our lives and see ourselves as if we were just one of them.' For some of us, the thought of this comes more often and stays longer. This type of person is described as 'reflective', 'self-conscious,' 'neurotic,' 'ironic,' 'pensive,' 'deep' etc." (1995, p. 11). The form of detachment referred to by Douglas-Mullen is not the detachment of the positivist scientist who stands at a separate, neutral, and objective distance from the subject matter of the research. It is the activity of experiencing oneself at an emotional distance from one's own set of conventions so that we see ourselves, as Douglas-Mullen says: as "just one of them." It is the experience of watching oneself while doing; the experience of being detached from one's own beliefs or sense making habits. Thus, we begin to lay the foundation for one of the central theses of philosophy, namely that reflection is a form of experience; not so much experience in the form of a sensory, but an existential experience. The experience of being detached from what we are involved in is a lived experience and it is an existential experienceone that defines itself in terms of an emotional detachment as when a person is preoccupied or 
"not there." This being "not there" for Heidegger is a dynamic state. It is a state of being drawn away from habitual conventions to disclosing the world in new ways. It is the space of insight, foresight, and hindsight. ${ }^{2}$ It is also the state of being in existential questioning, for existential questioning is that kind of question that involves mood, body, and cognition. It is this state of detachment that, for Heidegger allows us to question our heritage or historicity. Heidegger calls this kind of questioning "destruction," which, as Samuel Ijsseling maintains, "is ultimately oriented toward trying to direct attention to the unthought (das Ungedachte) in thinking and to the unsaid in saying. ... The unthought or the unsaid can be that which was never expressly thematized although it was presupposed in (philosophical) thinking and which, indeed, can be thought and said." (1982, p. 15)

For Heidegger, however, destruction applies not only to thought and saying but to habits of practice and conventions for doing as well. It is the unstated ways of doing things that is the subject matter of the form of questioning that arises in the disruption of destruction. For Heidegger, the link between questioning and disruption is crucial. Questioning occurs in experiences of disruption.

Thus, we can conclude this section by saying that philosophy is that kind of activity in which the assumptions behind a set of conventions for doing things are questioned in the context of the lived experience of disruption: in moods of estrangement or, more broadly speaking, in the context of a felt sense that things are not just quite right. This opens up the possibility for seeing and being in new ways. The view that philosophy is a destruction of assumptions (Plato, 2003,

\footnotetext{
${ }^{2}$ It is expressed technically by Heidegger in the following way: "What withdraws from us, draws us along by its very withdrawal, whether or not we become aware of it immediately, or not at all. Once we are drawn into the withdrawal, we are drawing toward what draws, attracts us by its withdrawal. And once we, being so attracted, are drawing towards what draws us, our essential nature already bears the stamp of 'drawing towards.' As we are drawing towards what withdraws, we ourselves are pointers pointing toward it."
} 
p. 553) is grounded in the point of departure of philosophy. The following section explores disruption in the context of a specific practice: that of project management. It will show how the assumptions on which current practices of project management have been built leave it poorly equipped to deal with the contingencies of the modern world, and open up the space for an existential hermeneutic approach to these practices.

\section{Project Management and the Disruption of Failure}

From the time when a project was some monumental feat of construction, such as the Hoover Dam or the Great Wall of China, it now seems that every activity, no matter how insignificant, can be conceived of as a project. If there is a piece of work to be done in a corporation that does not fit within the classification of an existing process, it will invariably be called a project. Some estimates suggest that 'projects' constitute more than $50 \%$ of work undertaken within the contemporary corporate sector (Flyvbjerg, 2012). Many companies, including IBM, have made project management the focus of their operating model (Zwikael \& Smyrk, 2011). Surprisingly, for such a ubiquitous method of organizing work, 'project management' as a formal discipline did not come into existence until the 1950s (Cicmil \& Hodgson, 2006a). It was during this period that extremely large and complex projects were undertaken by the U.S. Department of Defense, including the Polaris submarine and Apollo moon programs. It was in support of these programs that a number of new techniques, primarily in the area of scheduling, were developed. Principal among these techniques was PERT (Program Evaluation and Review Technique), which offered a probabilistic method for determining the likely duration of a project schedule (Weaver, 2007). Although the actual effectiveness of such techniques on the Polaris and Apollo programs is still debated (Koskela \& Howell, 2008), they quickly became popular, to the extent that their utilization is now 
more or less identified with the practice of project management itself (Cicmil \& Hodgson, 2006a). These practices have become, in terms of the philosophy discussed above, familiar and conventional.

Despite such a wide utilization of project management and a method that promises an effective and efficient delivery, a significant and increasing rate of project failure has been reported in contemporary practice across sectors. The Standish Group noted in their CHAOS summary report on IT industry projects that, effective 2009, there was:

A marked decrease in project success rates, with $32 \%$ of all projects succeeding which are delivered on time, on budget, and with required features and functions. $44 \%$ were challenged which are late, over budget, and/or with less than the required features and functions and $24 \%$ failed which are cancelled prior to completion or delivered and never used. (The Standish Group, 2009, p. 12)

A joint study by McKinsey and the BT Centre for Major Program Management at the University of Oxford, on 5,400 IT projects across a wide range of industries, found similarly disturbing results. Fifty percent of projects with a budget of US\$15 million or overran at least $45 \%$ over budget and they were delivered $7 \%$ behind schedule and delivered $56 \%$ less functionality than originally specified (Bloch, Blumberg, \& Laartz, 2012). However, reports on significant project failures measured against project management terms (the so-called iron triangle of delivery of cost, time, and quality) do not seem to be isolated to information technology (IT). In the research into large construction projects in over 20 countries, Flyvbjerg (2012) observed that "nine out of ten projects have cost overruns. Overruns of over $50 \%$ are common, while overruns of over $100 \%$ are not uncommon." Most significantly, Flyvbjerg noted: "Overruns have been constant for the seventy years for which data are 
available, indicating that no improvements in estimating and managing costs have been made over time.” (pp. 104-105)

As the philosopher Alasdair Macintyre (1984) noted, when there is a clear and expanding distinction between what the practice claims to be able to do and what it actually achieves, then the practice can reasonably be said to be in crisis:

The expert's claim to status and reward is fatally undermined when we recognise that he possesses no sound stock of law-like generalisations and when we realise how weak the predictive powers available to him are. $(1984$, p. 106)

What then, as 'experts,' are project management practitioners trying to predict? The 'iron triangle' of time, cost, and quality serves to define the parameters by which existing project management practice measures itself. These parameters are defined in the very early stages of the project life cycle and constitute a 'prediction' against which the project and project manager are ultimately measured (Atkinson, 1999). If we accept the project management practitioner's claim of predictive capacity in terms of this 'iron triangle,' then his or her expertise is fatally undermined by the high rate of failure in achieving those predictions (Hartley, 2009; Kerzner, 2001; Lewis, 1999). An analogy to this situation would be a medical practice such as surgery where, despite the existence of a uniform and consistently applied method, the majority of patients died after surgery. Eventually, a point of crisis is reached where the inherent inadequacy of the practice can no longer be ignored. As Koskela and Howell (2008) observe: "It is no exaggeration to claim that project management as a discipline is in crisis, and that a paradigm change, long overdue, has to be realised" (p. 297).

We will revisit the disruption of project failure and its existential nature in a subsequent section of this article. 


\section{Paradigm Crises as the Condition for Philosophy in Project Management}

The philosopher of science, Thomas Kuhn (1996), observed that all paradigms are built upon earlier ones. Our understanding is preconditioned by prior bodies of understanding that have evolved over generations. Understanding is therefore historically situated and it is only through an examination of the history of our present paradigms that contradictions within it can be revealed (Kuhn, 1996 pp. 1-9). In this, Kuhn shares the view of Heidegger that we are "always already" situated in a given context and that it is only through reflection on our existing ways of thinking and being that we can hope to change them.

However, current forms of reflection on project management practice actually do so from an ahistorical perspective that assumes the universality of present practices. In this form of research, existing project management methods may be conceived of as independent of historical forces and therefore immune to the contingencies of the past (Cicmil \& Hodgson, 2006a). Dreyfus and Rabinow (1983) argue there are two ways in which research can reinforce existing practices. The first way is 'presentism,' whereby "the historian takes a model, a concept, an institution, a feeling, or a symbol from his present, and attemptsalmost by definition unwittingly — to find that it had a parallel meaning in the past" (p. 118). The second way is 'finalism,' which 'tries to find the foundations of the present in some distant times, and analyse history as a finalized process that necessarily leads from that point to the present" (Lenfle, 2012, pp. 4-5).

In his historical treatment of ancient projects, Y.C. Chiu (2011) examines significant construction projects undertaken throughout the ancient world over approximately 3,500 
years. From the building of the Great Ziggurat of Ur (circa 2100 BC) to the construction of the Pantheon (118-126 AD), Chiu poses the hypothesis that "there are circumstances in different historical periods that affect the development of the areas of expertise and their application to project activities" (p. 14). In exploring the construction of these significant works, Chui achieves the stated aim to "increase understanding and appreciation of the profession of project management and situate it historically" (p. 11). There are, however, limitations to this kind of enquiry. The presentism of Chui's enquiry is explicit, as it views history through a contemporary perspective and, in so doing, imposes the assumptions and premises of existing project management practices onto earlier ones. As Chui (2011) puts it: "All concepts or analytical categories applied to history arise out of a contemporary standpoint. While the historical data must stand for themselves, the ideas used to organize them can appropriately come from present modes of understanding project management" ( $p$. 9). In the examination of the construction of the Roman Colosseum between $75 \mathrm{AD}$ and 82 $\mathrm{AD}$, Chui argues, "The Romans must have utilized disciplined and scientific project management to achieve their building aims" (p. 3) [our italics]. Chui concludes from this, and other similarly impressive projects in the ancient world, that "ancient civilizations practised the 'science' of project management" and that although "project management did not yet claim a technical definition during those ancient projects, the ancient builders understood and carried out the principles of project management in practice" (p. 3). Chui (2011) maintains: "Much of contemporary project management theory and practice lacks a historically conscious foundation, an awareness of how project management has developed throughout history" (p. 4). To this end Chui's work serves admirably to heighten the historical awareness of project management. Nonetheless, there is still the issue of the perspective through which the enquiry is conducted. As a normative historical enquiry, it serves to explain past events by situating them in contemporary practices, which in this case are modern project 
management techniques predicated on the language of science. In this sense, Chui's research is explanatory rather than critical.

Kozak-Holland's (2011) equally impressive work provides an example of 'finalism' in historical enquiry. Kozak-Holland argues that "a close analysis of these [ancient] projects highlights that supposedly recent project management disciplines were actively used in all these projects" (Kozak-Holland, 2011, p. 7). The implication of Kozack-Holland's (2011) point of view is that current project management methods are not a function of their historical background, but represent instead the discovery of a universal method for doing any kind of work. The previous history of project management is treated as a progressive uncovering of an already existing truth, the culmination of which is the articulation of that truth in contemporary project management practices. As Whitty and Shulz (2007) remark: "Some regard it [project management] as common-sense thinking and the natural outcome of logical reasoning and how work should be done" (p. 15) rather than the historical accident that it was.

Chui and Kozack-Holland's research is powerful in that it informs current project management practices via the richness of past project experiences; however, it remains wedded to existing project management practices. By projecting existing project management methods and practices back onto past projects, it seeks to explain those projects in terms of the present understanding or, alternatively, it seeks to consolidate the present paradigm by elaborating past practices as a steady, logical progression toward the present, fully realized practice. In either case, the existing project management practice remains unchallenged.

While Chui and Kozack-Holland make the explanatory nature of their analysis explicit, it is limited to a discussion of project management in the context of existing practice. To that end, their work is invaluable in providing project managers with a perspective on their current 
practices through reflection on earlier projects. The objective of research through such a perspective is normative in the sense that it "asserts that project management deserves and requires relevant historical exploration to fill the gaps in our knowledge," and the aim is not to challenge existing methods but to further consolidate them by "grounding it retrospectively in a trajectory that begins in ancient civilizations" (Kozak-Holland, 2011, p. 4).

The purpose of this criticism is not to dismiss the validity of traditional historical enquiry. Chui and Kozack-Holland's work serve an important purpose within the context of normal project management practice. The limitation of this kind of approach, however, is that the enquiry is conducted through the prism of contemporary project management practice. As such, the research assumes a privileged position in the examination that is superior to, and therefore independent of, the broader project management narrative. Such an approach serves to consolidate the existing, dominant project management language by retrospectively applying it to projects throughout history. Accordingly, previous ways of managing projects are viewed only as either more or less sophisticated examples of current project management practice (Hodgson \& Cicmil, 2007).

If we accept the argument that project management, as currently theorized and practiced, is in a state of crisis, then what alternative ways of thinking about practice are available to us? If we are to escape the confines of the normative research approaches outlined above, then the first challenge is to accept the possibility of other perspectives on practice. Kuhn (1996) argues when the anomalies within a practice increase, their impact on the stated aims of the practice can become so significant that they can no longer be accommodated within the confines of normal practice (pp. 23-35). To highlight his point, Kuhn used the example of astronomy. By the late 19th century, astronomers were regularly observing stars and planets in the 'wrong place,' at least according to where Newtonian theory said they should be. In the 
normal practice of astronomy, such an anomaly was treated as a misapplication of technique. Celestial bodies simply do not appear in the wrong place; they move according to Newtonian laws that yield extraordinarily accurate predictions. In this event, 'poor astronomical observation technique' might be the characterization of the cause of the anomaly. And if exactly the same observation by other astronomers did not yield the same anomaly, the assumption of poor technique would be a reasonable conclusion. What if, however, a large number of other astronomers begin to observe the same anomaly? Stars are not appearing exactly where they should, and planets are not behaving exactly as predicted. What then? Kuhn points out that to assume poor technique from all of them is irrational (1996, pp. 8183). When following a technique predicated upon a practice's fundamental principles consistently fails to yield a result the practice predicts, the practice is not internally consistent. Nor can such a problem be resolved by the normal techniques of the practice, because those techniques depend on the coherence of the practice for their efficacy (Kuhn, 1996,pp. 73-76).

In Heideggerian terms, the practice, and the practitioners themselves, now face more than an instrumental disruption to their activities. It may have begun as a failure of the tools and methods of the practice to deliver results, but the repeated failure of those tools has led to the practice itself being called into question. A practitioner's "way of being" in his or her practice is no longer on solid ground and he or she is facing an existential disruption. And, as Heidegger points out, such disruption requires a different kind of questioning than a mere examination of tools.

Kuhn argues that clear evidence of such disruption is a proliferation of theories attempting to resolve the anomalies being experienced, yet at the same time remaining within the context of existing practices (pp. 77-80). Over the last 20 years, several alternative theories that seek to 
resolve the anomaly of persistent project failure have emerged in project management practice, , particularly within the IT sector. Various project management methods, including rapid, agile, extreme, and radical (Thomsett, 2002; Wysocki, 2009), have been promoted as alternative theories better able to deal with the contemporary IT environment. These alternatives have achieved a degree of success in parts of the sector (predominantly software development) (DeCarlo, 2004; Morris, 2008; Perrin, 2008; Thomsett, 2002; Wysocki, 2009). As Kuhn (1996) observes, though, when new methods are generated within the space of a practice to deal with a crisis to the practice, they are invariably tightly constrained and therefore work only under highly specific circumstances (pp. 77-80). The project management approach called agile, for example, addresses a specific issue, pointed out as problematic in the successful delivery of software projects by a number of authors, namely 'unclear requirements' (Highsmith, 2010; Wysocki, 2009). Agile deals with unclear requirements by advocating a cyclical project approach, in which an immediate set of limited requirements is identified and the software development done to deliver it is within a 6 to 8 week timeframe. The cycle is then repeated with the next identified set of requirements (Highsmith, 2010). This method has proved very effective in dealing with the specific cause of unclear requirements by focusing on them one limited set at a time. This also has a flow-on effect into other causes of project failure, such as poor estimating and scope creep. By radically reducing the effective scope of the work, the parameters of time, cost, and specification are far easier to control (Wysocki, 2009). Although agile can be very effective in smaller, decentralized software projects where it is possible to deal with specific business requirements one at a time, this is not the case with large IT infrastructure projects. In these projects, requirements need to be considered holistically for an overall solution to be devised. There are also problems with being unable to compare competing bids in a competitive tendering process, and insufficient recourse to legal remedy in the event that anything goes 
wrong. In such project environments, agile remains problematic at best and has not been proven to be any more successful than more traditional methods (Ballard, 2011).

While the proliferation of alternative approaches, such as agile, within a practice may serve to extend the life of the paradigm on which the practice is based, they do not resolve the internal contradictions (Kuhn, 1996); they represent anomalies that practitioners cannot ignore. When the causes of project failure highlighted above are treated as symptoms of internal contradiction within the practice instead of deviations from good practice, an opportunity for different questioning — an existential questioning — offers itself. As Kuhn observes, "crises are a necessary pre-condition for the emergence of novel theories" (1996, p. 77). By revealing the internal contradictions, opportunities for revision to the practice that had previously gone unobserved may present themselves.

\section{The Disruption of Project Failure as Existential Disruption}

It is against this background of a practice in crisis that project management operates. What the existing approaches to project management practice are unable to encapsulate is that project management is a situated and contextual activity deeply imbued with meaning (Fincham, 2002). They cannot capture, nor deal with, the singular and intense existential disruption to practice that the constant failures outlined above are likely to generate among those who experience them. Traditional project management techniques attempt to provide answers to the questions posed by projects; however, in moments of disruption there is frequently no specific question to be answered and, instead, a project practitioner finds him or herself 'in question' as the everyday activities he or she conducts no longer carry the meaning they once had (Smith, 2006). As Heidegger observes, this goes much further than a mere 
suspicion that the tools of practice are failing, such as a carpenter might view a saw that he suspects is not cutting straight, or a hammer in which the head keeps slipping off. This is an existential suspicion, a questioning of the very 'way of being' that a project manager is engaged in is somehow 'not right'. It is in this space that the existential hermeneutic of Martin Heidegger (1993) operates.

Rather than focus on specific problems within the practice, an existential hermeneutic treats the disruption itself as a legitimate area of concern. Existential forms of disruption imply something other than a simple problem to be resolved. A problem is a piece of wood jamming a door and preventing it from opening. Forcing the piece of wood out of the door and using another door are the possible solutions to this problem.

Existential disruption is not like this. Existential disruption occurs when the relationship we have with our everyday activities no longer makes sense. Existential disruption tests something far more significant than our intellect or our skills - it tests our way of being in the world (Heidegger, 1993). This is the manner in which many project management professionals' experience their practice — not as a problem demanding a solution in the traditional sense, but as a problem with his or her 'way of being' a project manager.

So dominant are formal project management methods in the execution of projects that project managers can remain largely unaware of other ways of thinking or being in project management (Bresnen, 2006). Despite the repeated failures commented on earlier, project managers continue to utilize tools and techniques derived from principles whose philosophical justifications remain relatively unchallenged (Cicmil \& Hodgson, 2006b). As such, the existing project management methods can become accepted as 'the' way in which projects are delivered, rather than as simply one set of methods among the many required to 
successfully deliver a project (Ackroyd, 1994). The effect has been to limit the possibilities for project managers striving to deliver projects for the organizations they serve.

Kuhn's (1996) critique of practice offers a way forward for project management. As Kuhn points out, it was in the space of disruption to the practice of physics that Albert Einstein was able to account for the anomaly of celestial bodies in the wrong place. Rather than accept the fundamental premises of the existing Newtonian theory, Einstein challenged concepts such as the 'fixed' nature of time and space itself. ${ }^{3}$ Einstein's critique ultimately led to a revised practice of physics, which incorporated both the existing Newtonian laws and an extension to those laws that accounted for the observed anomalies (Kuhn, 1996, pp. 98-99).

We argue that a similar revision is required for the premise on which the practice of project management is based. The observed anomalies of project failure, particularly of IT projects, have reached the point where they are too pervasive to be ignored. No longer can such failures be understood within a simplistic cause-and-effect model, which assumes the current standard of practice. Both practitioners and researchers alike need to face the challenge of project failure by exploring 'ways of being' that do not view the present contradictions as something to be resolved but rather as a starting point for a different kind of practice.

Several researchers have already taken issue with the mainstream project management approaches to qualifying IT projects as successful or failed in practice: from questioning the legitimacy of the traditional project management iron triangle (time, cost, and quality criteria) as an evaluation framework (Atkinson, 1999), to exploring the use of declaratory powers to narratively redescribe a failing project as success (Fincham, 2002), to exposing the existential and behavioral effects of the failing project management science (Smith, 2006), to illuminating a resulting paradox in the possibility of linking the contemporary economic

\footnotetext{
${ }^{3}$ Further information regarding the challenge to the model of classical physics in the early 20th century can be found in Einstein (1961) Relativity: The Special and the General Theory, Three Rivers Press, New York.
} 
success and growth with the very 'failure' of major IT projects (Cicmil \& Braddon, 2012; Lindahl \& Rehn, 2007).

In the next section we will focus on the role of redescription as a philosophical practice essential for a project manager, because project managers are constantly working through disruptions of conventions to open up new possibilities.

\section{A Redescription of Project Management}

The existing conceptualisation of project management is a profession whose tools and techniques are founded on principles of natural science. Yet, in the evaluation of that profession (and therefore in 'the measure' of its professionals), we clearly invoke principles of a different kind. It can certainly be argued, and has been, that this does not matter and that project managers typically understand the distinction between their practice and science ( Morris, 2006). In this sense, project management principles can be viewed not as natural laws but simply as useful guidelines for getting a project 'funded' or 'set up' before another, more suitable practice is adopted to achieve and measure 'success.' This point of view certainly has merit, though it begs the question, however, as to what other, more adequate project management practices there could be? And why can we not encompass both the criteria for action and the criteria for judgment within the same language? As noted earlier in this article, Macintyre (1988) has observed that no community of practice or profession can consistently fail on its own terms and expect to survive. The principle suggestion to be developed in this section is that project management practitioners undertake what Rorty calls a 'redescription.' As Rorty states in "Contingency, Irony, and Solidarity:”

"All human beings carry about a set of words which they employ to justify their actions, their 
beliefs, and their lives. These are the words in which we formulate praise for our friends and contempt for our enemies, our long-term projects, our deepest self-doubts and our highest hopes. They are the words in which we tell, sometimes prospectively and sometimes retrospectively, the story of our lives. I shall call these words a person's 'final vocabulary."'(1989, p. 73)

The recognition that we carry with us in this 'final vocabulary,' not just the words for the attribution of success and failure, but also the criteria on which we judge them, provides the project manager with the possibility of adopting what Rorty calls the stance of the 'ironist,' for whom "anything can be made to look good or bad by being redescribed" (1989, p. 73). Without the weight of the final vocabulary of the project management meta-narrative - and its universal, abstracted, and contradictory search for knowledge - the project manager can instead see his or her role as negotiating the vast array of narratives that constitute the corporate world, each one carrying its own justification for truth, and for a brief moment, redescribing a small part of that world long enough to create something of value for the society he or she serves.

Rorty's contribution to understanding why project management is conducted the way it is and therefore the key to redescribing it, is to understand that the practices that constitute project management might have been different, and that many contemporary techniques and tools are actually the echoes of metaphors initiated in the scientific practices of the past and promulgated through to the present. These metaphors, applied inappropriately, have served to create a contradictory discourse that undermines the field of project management. By uncovering these metaphors and making them explicit, there is hope it will provide the possibility of alternative discourses to the project manager other than the success/failure 
dichotomy borrowed from the natural sciences and so inadequate for the business context within which projects actually operate. Rorty's practice of 'redescription' is offered, not as an alternative discourse in itself, but as a means by which new discourse can be created.

\section{Redescription: Coming to Terms with Language Games}

A project manager can learn to recognize that the various practices within a company constitute what Rorty describes as a "language game" (1982, pp. 166-169). Practices are a language-game by virtue of the fact that the terms contained within them mean what they mean by the consensus of the practitioners, rather than by any correspondence of those terms to something transcendental. In other words, there are no referents outside of a practice (i.e., the "game") to which the terms of a practice correspond. The terms of a practice achieve their meaning through reference to each other, and if removed from the context of the practice, may change their meaning, or be lost entirely. This applies to all the terms in the practice, regardless of how fundamental they are to its constitution (Rorty, 1989). To successfully recognize organizational language-games, a project manager cultivates an attitude of what Rorty calls "ironism" (1989, p. 73). An ironist recognizes that the various languages we use in our day-to-day practices are a game. An ironist sees that our values, beliefs, and ways of doing things are not rooted in nature itself but are conventions shaped by the history of a practice. The history of our practices determines which terms are used within them and which have fallen by the wayside over the course of time. It is therefore the history of our practices that determines our current ways of understanding our work (Rorty, 1989).

The attitude of the ironist reflected in that enquiry can be contrasted with those of us who feel the terms in which our work practices are inscribed are not a "game," but do indeed correspond with something eternal and immutable. For these people, Rorty argues, the 
language of their practice is a "final vocabulary," the terms of which cannot be argued about, and their meaning not debated (Rorty, 1989, p. 73). In making this contrast, there is no wish to disparage those of us for whom our language terms, and thus our beliefs, are somehow transcendental; because, as Rorty points out, this is nearly all of us. The perfect ironist is as difficult to find as the perfect fundamentalist (Rorty, 1999). We all have some terms in our language we are willing to debate and others we are not. Ironism, therefore, is a question of degree (Rorty, 1989). How far are we prepared to go, Rorty asks, in challenging the existing terms of our language?

This section argues that a project management practitioner needs to go further than most. Projects (especially large IT ones) can be inherently destabilizing to the organizations that create them; in fact, this is often a necessary condition for the changes that a project is charged with implementing (Thomsett, 2002). In such a time of organizational instability, the project manager needs to be cognizant that there are a multitude of language games clamouring for dominance within the organization, none of which can yet lay claim to it (Bresnen, 2006). In these circumstances, the project will become a vehicle for the realization of one or more competing organizational narratives (Fincham, 2002). Negotiating these multiple competing languages is a critical competency for the project management practitioner and one that the philosophical tool of ironism can assist in facilitating.

Rorty's philosophical stance of ironism argues against its universal best practice application. An ironist recognizes that languages evolve over time as the kinds of problems they face evolve; yet, he or she also recognizes there are languages that do not change and that do lay claim to being applicable in all situations at all times. Rorty describes these kinds of languages as "meta-languages" and they represent a particular challenge to the growth of human practices (Rorty, 1989, p. 122). We argued above that existing, formal project 
management methods could be characterized as a meta-language. The purpose of the project management meta-language, in this context, is to provide an overarching frame of reference for all problems within the organization. As such, the meta-language attempts to subsume all other specialist languages into it. The development of project management as a practice has been made extremely difficult by the existing formal project management meta-language, which seeks to ignore ambiguity of meaning between practices by imposing a language-game of its own (Cicmil \& Hodgson, 2006a).

The approach of the meta-language, in the form of formal project management practices, may be contrasted with the approach of an existential hermeneutic practitioner, who, through attunement to disruption and a reflective, non-defensive attitude, is able to recognize that attempting to marginalize other specialist languages, more often than not leads to disharmony and failure (Ivory, Alderman, McLoughlin, \& Vaughan, 2006). Rather, an ironic disposition to language allows the existential hermeneutic project manager to recognize the necessity of the multiple language-games in operation and work at the intersections between them. It is argued that one of the critical aspects of project management practice is to recognize the ambiguity of meanings brought about by the multiple specialist languages in operation in any large, contemporary organization (Ackroyd, 1994). As Linehan and Kavanagh (2006) observe, the concept of project management as a universalized practice able to transcend countries, cultures, organizations, and departments is very powerful. They believe that one of the reasons why the more formal project management meta-language has "flourished" is because of the "'silo" mentality in organizations wherein there are perceived communications barriers between departments or functional units" (p. 56). Individual business units are, they argue, "isomorphic," with their own "distinct languages - hence we have a sales language, a production language, an accounting language and so on" (p. 56). They note: "Project management has been proffered as a potent integrating mechanism to counter the (linguistic) 
fragmentation that is rampant in the contemporary organisational setting" (p. 56). What Linehan and Kavanah find most ironic in this solution is that it seeks to impose "yet another language into the mix, namely the language of project management, with its vocabulary of bar charts, resource histograms, work breakdown structure, project life cycle balanced matrix, project risk analysis, critical path method and so on" (Linehan \& Kavanagh, 2006, p. 56).

For language-games other than the natural sciences, the dispute has been whether any of the terms they deploy can refer externally, or whether our languages are entirely self-referential (Rorty, 1979). Rorty sees that we, as human beings, have a deep-seated desire to view the "noises and marks" that constitute our verbal and non-verbal communications as being "at one" with the world around us (Rorty, 1989, p. 37). Rorty (1979) argues that, most of the time, when we talk or write about something, we think we are talking or writing about the world 'as it is'. This leads us to think that, given enough time, we could describe anything with such detail that further description would be redundant and a different description would be impossible. Rorty claims that this is simply an idea, one our society did not always have, and one we can do without. He argues that we should abandon our propensity for adopting languages heavily invested in notions of truth and adopt languages invested in notions of what works (Rorty, 1979).

The privilege of the over-arching meta-language, or what Rorty (1979) refers to as "nature's own vocabulary" (p. 23), is a myth. An ironic stance toward project management practice would grant one language no more, or less, privilege than any other. During periods of disruption, existential threats, or crisis, there will be innumerable specialist languages at play in an organization, each encompassing its own notions of truth and its own criteria for success or failure (Reedy, 2008). A project management practitioner gains considerably from recognizing each of these languages and also recognizes that genuine progress occurs 
between them. In playing between languages, where the terms of one language-game do not necessarily translate meaningfully into another, for the project manager to seek a common standard of ground would actually be irrational (Arnold \& Fischer, 1994). Scott Berkun (2005) takes up this point in Art of Project Management:

It's not surprising then that the planning related books in the corner of my office disagree heavily with each other. Some focus on business strategy, others on engineering and scheduling processes (the traditional focus of project planning), and a few on understanding and designing for customers. But more distressing than their disagreements is that these books fail to acknowledge that other approaches even exist. This is odd because none of these perspectives-business, technology, customer-can ever exist without the others. More so, I'm convinced that success in project planning occurs at the intersections in these different points of view. Any manager who can see those intersections has a large advantage over those who can't. (p. 52)

As previously outlined, existing project management methods generally seek to achieve success through the application of the over-arching meta-language of formal project management practice. In doing so the meta-language of project management aims to render commensurable the disagreements to which Berkun (2005) refers. An existential hermeneutic approach of ironic redescription helps a project practitioner avoid granting one language primacy over another, recognizing the legitimacy of each of them in providing what Bolman and Deal referred to earlier in this article as "frames" of understanding the organization. For Bolman and Deal, a "frame" is a "mental model — a set of ideas and assumptions — that you carry in your head to help you understand and negotiate a particular 'territory"' (p. 14). They argue: "a good frame makes it easier to know what you are up against and, ultimately, what 
you can do about it" (p. 16). A frame can also limit our ability to master complex situations. Utilizing a Heideggerian motif, they observe: "Managers who master the hammer and expect all problems to behave like nails find life at work confusing and frustrating" (p. 27). They also argue that advanced managers deliberately "reframe" complex problems in order to challenge the assumptions in which the problem is based. "The wise manager," they observe, "wants at hand a diverse collection of high quality implements. Experienced managers also understand the difference between possessing a tool and knowing how and when to use it" (Bolman \& Deal, 2013, p. 27).

Similarly, Rorty (1979) presents redescription as a deliberate activity that renders existing terms within a language-game unfamiliar through their juxtaposition and/or contradiction with other terms within the same or different languages. The difference between Rorty's redescription and the tool of "reframing" offered by Bolman and Deal is that Bolman and Deal offer only four kinds of "frames." In these four frames, they "consolidate major schools of organizational thought and research into a comprehensive framework encompassing four distinct perspectives ... structural, human resource, political, and symbolic" (2013, p. 35). Each of the frames Bolman and Deal describes has fundamental axioms and principles that coincide with what Rorty refers to as a "final vocabulary." However, rather than limit our understanding of "final vocabularies" as belonging to one of only four perspectives, Rorty sees every human practice has having its own unique frame.

Rorty's view of language-games provides a far more nuanced and powerful perspective on the importance of language as a tool. A language-game is constituted by what Rorty refers to as "an agreed upon set of conventions about what counts as a relevant contribution, what counts as answering a question, what counts as having a good argument for that answer or a good criticism of it" (Rorty, 1979, p. 320). In Rorty's perspective, anywhere human beings 
find it necessary to work with one another they will generate their own language-game, one that is both parasitic on broader social languages, but also unique in its own particular deployment of linguistic terms (Rorty, 1989).

Heidegger (1996) suggests that we are what we practice, and that practice is determined by the language we grew up with or were "thrown" into, and we never got the chance to choose that language (p. 183). Rorty builds on this and describes as an "ironist" someone dissatisfied with the terms of his or her language-game, and as wanting to "get out from under their inherited vocabulary" (Rorty, 1989, p. 74). An ironist is someone ruefully aware that he or she has no "final vocabulary" (i.e., fixed and unarguable belief system), yet he or she recognizes he or she cannot get along without one, as he or she has to deal with people who do not share his or her same sense of contingency (Rorty, 1989, p. 74). Language, for Rorty, consists entirely of terms in a transition between one of two states: metaphor and dead metaphor (or literalness). A metaphor is simply the use of old words in unfamiliar ways, and it is the unfamiliarity of the usage that gives the expression its transformational power (Rorty, 1989). Sometimes, Rorty explains, an unfamiliar expression catches on and falls into general use. The expression becomes a familiar one and the metaphorical nature of it dies. It is now literal or 'dead.' Rorty uses the example of the 'mouth of a river' to highlight his point. When first used it must have seemed a strange expression, for only animals actually 'had' mouths, but something about the usage of it appealed, the imagery it excited stayed in our consciousness, and we now speak literally of the mouth of a river (Rorty, 1989). Although this linguistic process is itself well understood (Lakoff \& Johnson, 2003), what is critical in Rorty's conception of it is how it applies to all our linguistic terms. Every expression we have in our language originated as a metaphor and, through the contingencies and vagaries of our history, the ones we use have settled into literalness (Rorty, 1989). 
Ironism, for Rorty, is the recognition of the metaphorical nature of our language and the everpresent possibility of redescription. The disruptive effect of using old terms in new and unfamiliar ways is what the ironist seeks and sees as necessary in his or her personal projects of self-creation (Rorty, 1989). Frazier calls redescription the "engine of self-creation" and sees Rorty's ironist as wanting to "relate autonomously to their inherited vocabularies" by "getting out from under them" (Frazier, 2006, p. 462). Rorty's notion of self is therefore the product of the vocabulary we have available to us through chance, and we are free to play with that vocabulary and extend it by finding new terms. The alternative is to see some expressions in our vocabulary as permanently fixed and constant, as cohering to something outside of language and making a redescription of it nonsensical. The refusal to accept such expressions as only metaphors is to submit to the "final vocabulary" about which no further discussion can take place (Rorty, 1991, pp. 160-163).

The tension in Rorty's concept of redescription is the ironist's effort to transcend his or her final vocabulary, while at the same time acknowledging that it is not possible (or even, one could argue, desirable) to completely ignore it. As Rorty states: "Being is what final vocabularies are about. A final vocabulary is one we cannot help using, for when we reach it our spade is turned. We cannot undercut it because we have no meta-vocabulary in which to phrase criticisms of it" (Rorty, 1991, p. 37). Another way of putting it is to say who we are right now is defined by what we take for granted in our vocabulary. Who we might become depends on what we are prepared to 'play' with: "Historical narratives about social and intellectual movements are the best tools to use in tinkering with ourselves, for such narratives suggest vocabularies of moral deliberation in which to spin coherent narratives about our individual lives" (Rorty, 1991, p. 163). 
The notion of spinning coherent narratives serves to highlight one of the principal activities of redescription in the context of project management practice: the opening up of creative possibility within the project space through continual dialogue (Rorty, 1979). This contrasts sharply with the traditional view of conversation within more formal project management practices, which in many cases, seek to answer questions and close down dialogue through the application of a single, correct perspective. Todres (2007) points out that conversation should not be seen as providing "final and conclusive law-like absolutes" but rather provide "possibilities around which unique variations and actualities can occur" (p. 74).

In elaborating on conversation as the basis of an existential hermeneutic, Rorty (1979) offers the view that:

To see keeping a conversation going as a sufficient aim of philosophy, to see wisdom as consisting in the ability to sustain a conversation, is to see human beings as generators of new descriptions rather than beings one hopes to be able to describe accurately. (p. 378)

This article argues that if one were to replace the word "philosophy" in this quote with "project management," it would surely be a suitable aim for project management practice.

\section{Conclusion}

With reference to the works of Heidegger and Rorty, we have shown that being philosophical can provide a framework within which project managers can work with disruptions to develop their own and their clients' practices. To be philosophical is to work within the space of existential disruptions. Existential disruptions are those kinds of disruptions in which we can no longer take our fundamental conventions or assumptions for granted. The philosophical dimension of being a project manager includes the art of conversations for re-description in the 
space of disruption. Historically, the scientific ways in which project management has been conceived is to attempt to control for disruption.

For the project manager charged with the responsibility of delivering the aims of the project, the universal language of formal project management is meant to provide an over-arching framework within which the terms of control can be established, and the corresponding terms of success and failure can be attributed. For the project team members assigned from their various core disciplines to the "virtual and semi-permanent structure of the project," the language of formal project management is meant to provide "a single coherent framework" within which all the terms previously deployed in different areas can now be rendered commensurable with one another (Ivory et al., 2006, p. 331). The notion of the 'universal meta-language' and the control it is perceived to provide is a significant operating principle of project management practice and, this article argues, a significant weakness. The concept of the universal project management meta-language has its foundation in the rational framework of the natural sciences. The perceived success of the natural sciences in the centuries since the scientific method became popular has seen the word 'scientific' become analogous to 'truth' and any practice derived from scientific principles as sharing in this truthfulness (Rorty, 1979). The problem remains that the scientific language on which formal project management methods are largely based, uses individual terms to refer externally to physical objects, and it is that reference that is assumed to provide science with its objectivity. In order for the language of science to operate successfully, all aspects of the environment need to be reduced to quantifiable, measurable natural objects, or scientific language has no basis on which to operate (Chalmers, 1976). However, this kind of disinterested objectivity has little bearing on the embodied issues that project managers regularly face. Project management practice typically confronts issues of meaning that has individual human beings as the external referents rather than inanimate objects. As noted 
earlier by Heidegger, reflection on our ways of being in practice, are not the same as reflection on the objects of scientific enquiry.

A successful project manager, this article argues, would resemble an ironist, insofar as he or she shares with the ironist the lingering feeling he or she was born into the "wrong language game" and thus tends to refer to the language of formal project management with terms such as "game," "perspective," and "conceptual framework" (Rorty, 1989, p. 75). The awareness of the contingency of his or her vocabulary provides the ironic project manager with the opportunity to redescribe his or her language-games. This view can be contrasted with the more traditional practitioner, who does not want to redescribe the language-game of project management he or she simply wants it "accepted as it is" (Rorty, 1989, pp. 73-75). The existential hermeneutic philosophical approach outlined here allows project managers to view disruption as an opportunity to disclose ways of reframing, or redescribing a project. What Einstein once said of a scientific problem can also be said of a project problem: the problem is never solved in the terms in which it is formulated. The resolution of a problem or project requires a new way of seeing things. As we have indicated in this article, one way this can occur is through the practice of redescription, which occurs in moments of existential disruption. Project management as a discipline is going through such an existential disruption. The traditional scientific models are no longer a sufficient condition for effective practice and for establishing trust in ways of practicing. As project managers, not only would we gain from becoming more philosophical, we also gain from exploring philosophy as an opportunity for working through the existential disruptions to our own underlying conventions and assumptions. 


\section{References}

Ackroyd, S. (1994). Re-creating common ground: Elements of post-paradigmatic organization studies In M. Parker \& J. Hassard (Eds.), Towards a new theory of organisations (pp. 269-297). London, England Routledge.

Arnold, S.J., \& Fischer, E. (1994). Hermeneutics and consumer research. Journal of Consumer Research, 21(June), 55-69.

Atkinson, R. (1999). Project management: Cost, time and quality, two best guesses and a phenomenon, its time to accept other success criteria. International Journal of Project Management, 17(6), 337-342.

Ballard, M. (2011). Public sector IT: exploring the challenges involved in large-scale IT in the public sector. Computer Weekly.Com. from http://www.computerweekly.com/blogs/public-sector/

Berkun, S. (2005). The art of project management. Sebastopal, CA: O'Reilly.

Bloch, M., Blumberg, S., \& Laartz, J. (2012). Delivering large scale IT projects on time, on budget, and on value. McKinsey Quarterly, 27(Fall).

Bolman, L.G., \& Deal, T. E. (2013). Reframing organisations: Artistry, choice, and leadership (5th ed.). San Francisco, CA: Jossey-Bass.

Bresnen, M. (2006). Conflicting and conflated discourses? Project management, organisational change and learning In D. Hodgson \& S. Cicmil (Eds.), Making projects critical (pp. 68-89). Hampshire, UK: Palgrave.

Chalmers, A. (1976). What is this thing called Science? St. Lucia: University of Queensland Press.

Chiu, Y.C. (2011). A history of ancient project management: From Mesopotamia to the Roman Empire. The Netherlands: Eburon.

Christensen, C M., \& Overdorf, M. (2000). Meeting the challenge of disruptive change. Harvard Business Review(March-April).

Cicmil, S., \& Braddon, D. (2012). 'Fading Glory? Decision-making around the project: How and why "glory" projects fail.' In T. Williams \& K. Samset (Eds.), Project Governance - Getting Investments Right (pp. 221-255). Basingstoke, UK: Palgrave Macmillan.

Cicmil, S., \& Hodgson, D. (2006a). Are projects real? The PMBOK and the legitimation of project management knowledge. In D. Hodgson \& S. Cicmil (Eds.), Making projects critical (pp. 2950). Hampshire, UK: Palgrave.

Cicmil, S., \& Hodgson, D. (2006b). New possibilities for project management theory: A critical engagement. Project Management Journal, 37(3), 111-122.

DeCarlo, D. (2004). Extreme Project Management: Using leadership, principles, and tools to deliver value in the face of volatility. San Francisco, CA: Jossey-Bass.

Dreyfus, H. L., \& Rabinow, P. (1983). Michel Foucault: Beyond structuralism and hermeneutics (2nd ed.). Chicago, IL: University of Chicago.

Dru, Jean-Marie. (1996). Disruption: Overturning conventions and shaking up the marketplace. New York, NY: John Wiley and Sons.

Fincham, R. (2002). Narratives of success and failure in systems development. British Journal of Management, 13(1), 1-14.

Flores, F.. (2000). Heideggerian thinking and the transformation of business practice. In M. Wrathall \& J. Malpas (Eds.), Heidegger, coping, and cognitive science: Essays in honor of Hubert L. Dreyfus,- Volume 2 (pp. 271-291). Cambridge, MA: MIT Press.

Flyvbjerg, B. (2012). Why mass media matter and how to work with them: Phronesis and megaprojects. In B. Flyvberg, T. Landman \& S. Schram (Eds.), Real social science: Applied phronesis (pp. 95-121). Cambridge, UK: Cambridge University Press.

Frazier, B. (2006). The ethics of rortian redescription. Philosophy and Social Criticism 32(4), 461492.

Group, The Standish. (2009). CHAOS summary report on IT industry projects Retrievedfrom: http://www1.standishgroup.com/newsroom/chaos_2009.php

Hartley, S. (2009). Project management: Principles, processes and practice (2nd ed.). Frenchs Forest, New South Wales: Pearson Prentice Hall. 
Heidegger, M. (1993). Martin Heidegger: Basic writings. San Francisco, CA: Harper Collins.

Heidegger, M. (1996). Being and time (J. Stambaugh, Trans.). Albany, NY: SUNY Press.

Highsmith, J.A. (2010). Agile project management: Creating innovative products. Boston, MA: Pearson Education.

Hodgson, D., \& Cicmil, S. (2007). The politics of standards in modern management: Making 'the project' a reality. Journal of Management Studies, 3 Summer(44), 431-450.

IJsseling, S. (1982). Heidegger and the destruction of ontology. Man and World, 16, 3-16.

Ivory, C., Alderman, N., McLoughlin, I., \& Vaughan, R. (2006). Sense-making as a process within complex projects. In D. Hodgson \& S. Cicmil (Eds.), Making projects critical (pp. 316-334). Hampshire, UK: Palgrave.

Kerzner, H. (2001). Project management: A systems approach to planning, scheduling, and controlling (7th ed.). New York, NY: John Wiley and Sons, Inc.

Koskela, L., \& Howell, G. (2008). The underlying theory of project management is obsolete. IEEE Engineering Management Review, 36(2), 22-34.

Kozak-Holland, M. (2011). The history of project management. Ontario, Canada: Multi-Media Publications.

Kuhn, T. S. (1996). The structure of scientific revolutions (3rd Edition ed.). Chicago, IL: The University of Chicago Press.

Lakoff, G., \& Johnson, M. (2003). Metaphors we live by. Chicago, IL: The University of Chicago Press.

Lenfle, S. (2012). Towards a genealogy of project management: Sidewinder and the management of exploratory projects. Paper presented at the European Group for Organisational Studies (EGOS), Helsinki, Finland.

Lewis, J. P. (1999). The project manager's desk reference: A comprehensive guide to project planning, scheduling, evaluation and systems. New York, NY: Mcgraw-Hill.

Lindahl, M., \& Rehn, A. (2007). Towards a theory of project failure. International Journal of Management Concepts and Philosophy, 2(3), 246-254.

Linehan, C., \& Kavanagh, D. (2006). From project ontologies to communities of virtue. In D. Hodgson \& S. Cicmil (Eds.), Making projects critical (pp. 51-67). Hampshire, IL: Palgrave.

MacIntyre, A. (1984). After virtue: A study in moral theory (2nd ed.). Notre Dame, IN: University of Notre Dame Press.

Macintyre, A. (1988). Whose justice? Which rationality? Notre Dame, IN: University of Notre Dame Press.

Morris, P. (2006). Making the management of projects critical. In D. Hodgson \& S. Cicmil (Eds.), Making projects critical (pp. 335-347). Hampshire, UK: Palgrave.

Morris, R.A. (2008). Project Management that works: Real-world advice on problem solving, communicating and every thing else you need to know to get the job done. New York, NY: Amacom.

Mullen, J.D. (1995). Kierkegaard's philosophy: Self-deception and Cowardice in the present age. New York, NY: University Press of America.

Nietzsche, F. (1969). On the geneology of morals. Toronto, Canada: Random House.

Perrin, R. (2008). Real world project management: Beyond conventional wisdom, best practices, and project methodologies. Hoboken, NJ: John Wiley \& Sons.

Plato, (2003). The Republic.(D. Lee, Trans.) London, England: Penguin Books

Reedy, P. (2008). Mirror, mirror, on the wall: Reflecting on the ethics and effects of a collective critical management studies identity project. Management Learning, 391(1), 57-72.

Rorty, R. (1979). Philosophy and the mirror of nature. Princeton, NJ: Princeton University Press.

Rorty, R. (1982). Consequences of pragmatism (essays: 1972-1980). Minneapolis, MN: University of Minnesota Press.

Rorty, R. (1989). Contingency, irony, and solidarity. Cambridge, UK: Cambridge University Press.

Rorty, R. (1991). Essays on Heidegger and others-Philosphical papers, volume 2. Cambridge, UK: Cambridge University Press.

Rorty, R. (1999). Philosophy and social hope. London, England: Penguin Books.

Schumpeter, J. (1955). Imperialism and social classes: Two Essays by Joseph Schumpeter. Cleveland, $\mathrm{OH}$ : Meridian Books. 
Segal, S. (2015). Management practice and creative destruction: existential skills for professional practice. Farnham, UK: Ashgate Gower.

Smith, C. (2006). A tale of an evolving project: Failed science or serial reinterpretation. In D. Hodgson \& S. Cicmil (Eds.), Making projects critical (pp. 190-204). Hampshire, UK: Palgrave.

Spinosa, C., Flores, F., \& Dreyfus, H. (1997). Disclosing new worlds: Entrepreneurship, democratic action, and the cultivation of solidarity, Cambridge, MA: Massachussetts Institute of Technology.

Thomsett, R. (2002). Radical project management. Upper Saddle River, NJ: Prentice Hall PTR.

Todres, L. (2007). Embodied enquiry: Phenomenological touchstones for research, psychotherapy and spirituality. New York, NY: Palgrave Macmillan.

Weaver, P. (2007). A brief history of project management: Is our profession 50 or 5000 years old? Project, 19(1).

Whitty, S. J., \& Schulz, M. F. (2007). The impact of Puritan ideology on aspects of project management. International Journal of Project Management, 25, 10-20.

Wysocki, R. (2009). Effective project management: Traditional, agile, extreme. Indianapolis, IN: Wiley Publishing.

Zwikael, O., \& Smyrk, J. (2011). Project management for the creation of organisational value. London, England: Springer-Verlag. 